Intersections

Canadian Journal of Music

Revue canadienne de musique
Intersections

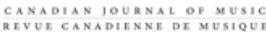

\title{
Neglected Canadian Orchestral Music
}

\section{Robin Elliott}

Volume 33, numéro 2, 2013

Musical Perspectives, People, and Places: Essays in Honour of Carl Morey

URI : https://id.erudit.org/iderudit/1032699ar

DOI : https://doi.org/10.7202/1032699ar

Aller au sommaire du numéro

Éditeur(s)

Canadian University Music Society / Société de musique des universités canadiennes

\section{ISSN}

1911-0146 (imprimé)

1918-512X (numérique)

Découvrir la revue

Citer cet article

Elliott, R. (2013). Neglected Canadian Orchestral Music. Intersections, 33(2), 127-139. https://doi.org/10.7202/1032699ar
Résumé de l'article

Cet article examine une série d'oeuvres orchestrales de six compositeurs canadiens : Rodolphe Mathieu, Colin McPhee, John Weinzweig, Harry Somers, Istvan Anhalt, et R. Murray Schafer. Malgré les réalisations professionnelles considérables et les carrières remarquables de ces compositeurs, chacun d'entre eux a composé au moins une oeuvre orchestrale qui n'a pas emporté l'adhésion du public ou qui n'a même jamais été créée en concert. Dans cet article, on tente de compendre pourquoi ces compositions ne se sont pas taillé une place dans le répertoire, ce qui soulève des questions plus générales au sujet du répertoire orchestral canadien.
Copyright @ C Canadian University Music Society / Société de musique des universités canadiennes, 2013
Ce document est protégé par la loi sur le droit d'auteur. L'utilisation des services d'Érudit (y compris la reproduction) est assujettie à sa politique d'utilisation que vous pouvez consulter en ligne.

https://apropos.erudit.org/fr/usagers/politique-dutilisation/ 


\section{NEGLECTED CANADIAN ORCHESTRAL MUSIC}

\section{Robin Elliott}

Many years ago, a Berlin music critic wished to prepare his readers for the local premiere of a difficult orchestral piece. The composer had many successful works to his credit, but the critic feared that his most recent piece might fail, so he launched a spirited defence of it before a note had been heard. "How can the receiving public ... fancy itself to be called upon to judge an artistic work?" he asked. "How can they think themselves competent to dispose, in an hour or two, of something that cost a talented artist the best years of his life?" He then went on the offensive: "One should seek the causes for the failure of an artwork to make a good impression in oneself, not in the work" (Cook 1993, 69). The critic was A.B. Marx, the year 1826, and the work Beethoven's Ninth Symphony.

This article deals with neglected orchestral works by six Canadian composers: Rodolphe Mathieu, Colin McPhee, John Weinzweig, Harry Somers, Istvan Anhalt, and R. Murray Schafer. While these men may not enjoy the fame of Beethoven, they are talented professional creative artists with many successful compositions to their credit. Despite their achievements, they have at least one orchestral work in their catalogue that failed to make a good impression with the musical public or has never been heard in live performance. Despite Marx's admonition, we will seek the causes for these failures in the compositions themselves, while also considering how these works illustrate broader issues relating to the Canadian orchestral repertoire.

\section{The Role of Orchestras in Canadian Society}

In 1942 Ettore Mazzoleni voiced optimism about the future for orchestras in Canada: "We were once a singing people. Now we are fast becoming a playing people-that is, musically speaking. What the choir was fifty years ago, the orchestra soon will be. This is an orchestral age in the making" $(1942,5)$. By the late 1960s, Mazzoleni's prediction had come true. R. Murray Schafer, however, voiced serious reservations about the orchestra as an institution and about its role in the musical life of Canada. In a lecture to the Royal Society of Canada in 1967 , he stated, "It is a sorry fact that every city in Canada aspires to acculturation in the same way, through the acquisition of a symphony orchestra and later perhaps an opera company. We wish to have pets and we immediately go after the dinosaurs ... From St. John's to Victoria the same tedious pattern; the same third-rate semi-professional orchestras groaning annually through the same pot-boiler repertoire; the same patient audiences trying not to look headachy" $(1984,41)$. Putting the matter in a more positive light, Gilles Potvin noted, "It is no exaggeration to say that it is the symphony orchestras 
which form the base and nerve-centre of Canadian musical life" (Potvin 1969, 145). Across the country, urban music-making in the realm of classical concert music during the course of the twentieth century often coalesced around the creation of a civic orchestra. The oldest continuously operating orchestra in Canada is the one in Quebec City, which was founded in 1902; by 1980 the Encyclopedia of Music in Canada could report that there were more than 100 orchestras in Canada, though only four offered players a full-time year-round contract (Winters 1981, 703).

Like having a top-tier professional sports team, having a professional orchestra can be a focus for civic pride as well as musical excellence. During the Charles Dutoit years (1977-2002) at the Montreal Symphony, the orchestra gained a major international profile from its frequent tours and dozens of successful recordings. The city of Montreal capitalized on this attention in 1983 with a poster campaign that featured a picture of Dutoit with the caption "La fierté a une ville." For a composer, having a work performed by an orchestra is also a cause for pride, and an occasion that brings the artist's work to the attention of a larger audience than most other types of performances offer. But all too often that glory is fleeting, with the work given a single performance that is quickly forgotten, condemning the work to obscurity.

\section{The Canadian Orchestral Canon: Reality or Fiction?}

It could be argued that all Canadian orchestral music has fallen on deaf earsthat there is no canon of popular Canadian orchestral music. Taking the contrary view, John C. Reid and Bob Clark drew up a list of 121 works by Canadian composers that they considered to be success stories (Reid and Clark 2001). These works were drawn from the total corpus of Canadian orchestral musicsome 2,500 compositions in 2001. Their criteria for success included repeat performances by more than one orchestra across the country and abroad; works that had been broadcast, recorded and/or published; or works that had won a Juno Award for Best Classical Composition. While the authors stated, "It may be too soon to proclaim a definitive Canadian orchestral canon" (150) their article was a step in that direction. In response to this article, John Beckwith wrote a strongly worded and closely argued rebuttal not just of their list, but also of the very idea of a Canadian orchestral canon (Beckwith 2002). Beverley Diamond has similarly argued that anti-canonization is a characteristically Canadian phenomenon that distinguishes music (and music scholarship) in Canada (Diamond 2000, 72).

A more systematic study of performances of Canadian orchestral repertoire was undertaken by Robert John Fraser (2008). He examined the repertoire of six of the eighteen most prominent orchestras in Canada from 1980 to 2005. He chose the two largest orchestras (Toronto, Montreal), two medium-sized orchestras (Calgary, Winnipeg), and two smaller orchestras (London, Victoria). There were 1,574 performances of Canadian orchestral pieces by those six orchestras during these twenty-five years, by 307 different composers. Fraser notes that of the 121 works on Reid and Clark's list of "successful" Canadian 
orchestral repertoire, 31 received no performances at all by these six orchestras from 1980 to 2005 (26). He found that forty-four composers enjoyed ten or more performances of their music during this period; R. Murray Schafer heads the list with fifty-seven performances of 27 different works. But perhaps the most striking fact that emerges from Fraser's study is that of the 934 works on his list, 677 were heard only once, providing statistical verification of the phenomenon of once-only performances of new Canadian orchestral works and seriously undermining the idea of a Canadian orchestral canon.

Why do so many Canadian orchestral works never get a second (or first) hearing? There are thousands of orchestral works by Canadian composers that form what might be called an "anti-canon," works so neglected they have yet to find an audience. I shall offer some possible reasons why these works have not achieved even a small measure of popularity with orchestral musicians, the listening public, conductors, managers, and others involved in selecting which pieces in the orchestral repertoire are performed. It would be interesting to do a comparative study in order to evaluate whether orchestral works by Canadian composers are more neglected than those by composers in other countries. John Weinzweig (as quoted in Beckwith and Cherney 2011, 60) stated that Canadian composers are the "most unpublished, unheard, unperformed and unpaid composers in the Western world," but a good deal of comparative research would be necessary before such a statement could be evaluated and either verified or proven false.

\section{Case Studies of Neglected Canadian Orchestral Music}

To place this study in historical perspective, let us consider orchestral music by Canadian composers of earlier centuries. Before the twentieth century, no orchestras in Canada enjoyed sufficient stability that would lead us to call them "permanent." As the Encyclopedia of Music in Canada reminds us, even the "finest orchestra, playing year-round to full houses at the highest feasible ticket prices, cannot earn as much as it costs" (Winters 1981, 703); it is not surprising, then, that our prudent and penny-conscious ancestors were loath to support such institutions full-time. Given the lack of permanent orchestral ensembles to work with or hear, few Canadian composers in the nineteenth century devoted much attention to orchestral composition. Helmut Kallmann and Elaine Keillor have provided a brief overview of the few known Canadian orchestral compositions dating between 1790 and 1925 (Kallmann 1990, vi-viii; Keillor 1994, ix-xii). Of those composers active in Canada during this period who did write for orchestra, few managed to hand their works on to posterity. Joseph Quesnel, a contemporary of Mozart, is said to have written symphonies, but if he did, these works now seem to be irretrievably lost. The first orchestral work by a Canadian composer that has been preserved is Ouverture Patrie by Calixa Lavallée, the composer of Canada's national anthem and a contemporary of Georges Bizet. The score is dated "Paris, 12 August 1874"; Keillor speculates that the work may have been played in Paris at that time (Keillor 1994, ix). 
For the first case study of neglected orchestral music, we shall remain in Quebec but move into the early twentieth century. Rodolphe Mathieu was born near Quebec City in 1890 and was a pupil of Vincent d'Indy at the Schola Cantorum in Paris in the 1920 (see Lefebvre 2004 for a discussion of Mathieu's career). During the 1920 and 1930 he wrote a series of piano pieces and chamber works that are among the earliest examples of musical modernism by a Canadian composer. But after 1934 he devoted his energy to the career of his son André (1929-1968), a child prodigy heralded as the Canadian Mozart and said by Albert Einstein to be "the greatest proof of genius I have ever encountered" (Renaud 2009). André was also a composer, and his music has had something of a revival in recent years, thanks to the efforts of the Quebec pianist Alain Lefèvre, who has made several recordings of the piano works of André Mathieu and was the musical director for the movie L'enfant prodige (2010), a biopic about Mathieu's life directed by Luc Dionne. The younger Mathieu, like so many child prodigies, failed to grow up into a successful adult musician-he became an alcoholic and died at the age of thirty-nine. The renewed interest in his music has so far failed to ignite much interest in the work of his father Rodolphe Mathieu, who was a more adventurous composer. André wrote in a rather conservative Romantic style, whereas Rodolphe was a modernist; his style ranges from a rich post-Romantic chromatic idiom to atonality.

Rodolphe Mathieu's Three Preludes were written during the First World War in Quebec, before he went to Paris to study. Originally for piano, the Three Preludes were later orchestrated by Mathieu; they are subtle, atmospheric works in the style of Debussy. With a total duration of just four minutes, the preludes are taxing for neither the orchestra nor the audience; perhaps the main thing militating against their popularity is their very brevity. Mathieu was so busy orchestrating the career of his son that he neglected his own work as a composer; as a result, he became Leopold Mozart to his son's Wolfgang Amadeus, with all the attendant obscurity and lack of recognition that that comparison suggests.

One Canadian orchestral work that will never be heard is Piano Concerto No. 2 by the Montreal-born composer and ethnomusicologist Colin McPhee. As with André Mathieu, there has been renewed interest in McPhee's career recently, especially since the publication in 1990 of Carol J. Oja's detailed biography (Oja 1990). McPhee's orchestral work Tabuh-Tabuhan, which evokes the gamelan music of Bali, has been popular ever since Leopold Stokowski conducted the New York premiere of the work in 1953, and McPhee's Concerto for Piano and Wind Octet is performed fairly frequently as well. Although he was born in 1900 in Montreal, McPhee grew up in Toronto and lived there until 1924, apart from a three-year period in Baltimore studying at the Peabody Conservatory. On 15 January 1924 he appeared as the soloist with the New Symphony Orchestra, predecessor of the Toronto Symphony, to play his Piano Concerto No. 2 (No. 1 had been done with the Peabody Orchestra in Baltimore in 1920). In the scherzo movement of the concerto, the young composer wanted to have a percussionist shake Chinese glass wind chimes. "This was never performed," McPhee complained to a friend; "to my disappointment the 
conductor thought it nonsense" (Oja 1984, 3). The conductor was the Vienneseborn musician Luigi von Kunits, who was not favourably disposed to avantgarde music; it is no surprise that he vetoed McPhee's wind chimes (see Elliott 2014, 252-53, for an account of Kunits's views on modern music). A review of the concerto in a local music journal noted that the work "depicts very forcibly the modern spirit of youth-headstrong, heedless, at times quite unreasonable" (Potvin 1981). No subsequent performances of the concerto were given; McPhee's disagreement with Kunits over the use of the wind chimes likely did not encourage the conductor to want to promote the work or perform it again. McPhee moved many times during his life; he was brilliant but undisciplined and in the end succumbed to alcoholism and depression, like André Mathieu. At some point during his journeys, the only manuscript copy of his two piano concertos vanished.

With the third case study, we move into the modern era. This is a work by the composer John Weinzweig, who died in 2006 in Toronto, his native city, at the age of ninety-three. Weinzweig's struggles to win institutional support for and recognition of the creative efforts of twentieth-century Canadian composers were legion, and he remained dedicated to this issue for his entire life. He criticized the $\mathrm{CBC}$ for not broadcasting and supporting the music of Canadian composers enough, even though he received many commissions from that very organization. He also took the Toronto Symphony to task: "The TSO has become irrelevant to my music," he wrote in 1992 (as quoted in Beckwith and Cherney 2011, 18). He made his peace with the Toronto Symphony late in life, and indeed his last public appearance was on 1 April 2006 when he was escorted onstage for a standing ovation after the orchestra performed the recently completed revised version of his 1941 Rhapsody for Orchestra. ${ }^{1}$

One of Weinzweig's neglected works is his Violin Concerto, which was written in the early 1950 s in his mature twelve-tone idiom. While Weinzweig's dream as a young composer had been to write orchestral music, he found more opportunities to write chamber music as his career developed. His style, which features sparse textures and favours complex motivic interplay among the instruments, is well suited to chamber ensembles, but these features are also in evidence in the Violin Concerto, which is written for a classical orchestra the same size as the one Beethoven used for his Violin Concerto. Weinzweig wrote the work using a twelve-tone row, but uses $\mathrm{D}$ as a sort of pitch centre, perhaps in homage to the many great violin concertos in D: Mozart No. 4, Beethoven, Paganini, Brahms, Sibelius, Tchaikovsky, Prokofiev No. 1, and Korngold, among many others. Weinzweig's Violin Concerto is in standard concerto form - three movements in a fast-slow-fast tempo sequence-and lasts half an hour in performance. It was premiered in 1955 on a $\mathrm{CBC}$ radio broadcast by the Toronto-born violinist Albert Pratz, who was Weinzweig's exact contemporary and later became the concertmaster of the Toronto Symphony; the same

1 A disappointing postscript to Weinzweig's relationship with the Toronto Symphony is that during the Weinzweig centennial year (2013) the orchestra did not program a single work by Weinzweig. 
soloist later performed the work on television and recorded it. ${ }^{2}$ But it was not until fifteen years after the broadcast premiere that the work was finally heard in live performance, when the young violinist Andrew Dawes performed it in Vancouver. ${ }^{3}$

Pratz's recording of the concerto is at odds with the written score. The work seems to have entered the canon of Canadian orchestral music on the strength of this one recording, which was re-released on CD in 2002, but it is unlikely that the concerto has been heard in live performance more than a handful of times. ${ }^{4}$ Pratz once told a story that illustrates one problem with this recording. In 1963 Pratz was riding in his car and heard on the radio a performance of a violin work that intrigued him. He tried to identify the work and the performer, guessing the work to be that of a contemporary composer, possibly American. The performer, he thought, might be Alfredo Campoli, who often performed contemporary music. He was intrigued by the broadcast and stayed in his car until the conclusion of the program. Pratz was stunned when the announcer said, "That was the Concerto for Violin and Orchestra by Canadian composer John Weinzweig, played by Albert Pratz" (Anonymous 1963). Pratz had recorded the work just three years earlier but so little identified with the work that he did not recognize his own recording of it! The spotty performance history of this concerto may result from the fact that the initial soloist did not particularly appreciate the music and seems to have regarded performing it as a chore rather than an opportunity to promote Weinzweig's music.

A fourth work that I propose for this anti-canon is by one of Weinzweig's most successful students-Harry Somers. Somers was born in Toronto in 1925 and died there at the age of seventy-three in 1999. Somers was an outstanding pianist as a young man and toyed with the idea of a career as a concert performer on that instrument. Like Berlioz, he also played the guitar very well, but he never studied any of the orchestral instruments seriously. Nevertheless, by his mid-twenties, he had written North Country, a suite for string orchestra that has been performed frequently, and he went on to write a good deal of orchestral music. Five of his orchestral compositions are in Reid and Clark's list of the popular Canadian orchestral repertoire, and on Fraser's list there were thirty-six performances of fourteen different works by Somers between 1980 and 2005. The work to be discussed here is Sterephony, which has been recorded (Somers 2011) but has been performed only twice.

The first performance was a landmark event and makes an interesting case study in the reception of experimental music in Canada in the 196os. Just as

2 The details of the recording and its reissues are in Beckwith and Cherney 2011, 377. The performance for CBC TV took place in April 1971, with the Toronto Symphony conducted by Victor Feldbrill, and Albert Pratz as the violin soloist.

3 The first movement of this performance is available on track 3 of the CD included in the recent book of essays on Weinzweig (Beckwith and Cherney 2011).

4 The violinist Katherine Unrau performed Weinzweig's Violin Concerto with the Kingston Symphony under conductor Pierre Simard on 3 February 2013; this was likely the first performance of the work in nearly forty years. The most recent of three recordings available on the Canadian Music Centre's streaming audio service Centrestreams (https://www.musiccentre.ca/centrestreams/) dates from ca. 1975. 
Marx wrote an article to prepare Berlin audiences for Beethoven's Ninth Symphony in 1826 , so too in this case there was an article-in fact, two articles-to prepare Toronto audiences for Stereophony. Harry Somers himself wrote one for the periodical Music across Canada, a publication of the Canadian Music Centre (Somers 1963), and John Kraglund, the music critic for the Toronto Globe and Mail, wrote the other, which appeared in the newspaper a few days before the first performance, which took place on 19 March 1963 (Kraglund 1963a). Somers explains that the title, Stereophony, "describes the distribution of the orchestral forces throughout the hall, the intention being to utilize the stereophonic possibilities inherent in the concert hall" (Somers 1963, 27). The disposition went far beyond a simple antiphonal arrangement; the musicians were divided into over two dozen groups and were spread around the entire auditorium-most of the strings were on the stage, but wind, brass, and percussion groups were positioned on the catwalk above the stage, as well as on the floor and in both balconies of Massey Hall. In this way the sound was spread out horizontally and vertically, to make maximal use of the performing space. Listeners in different parts of the hall experienced the work from different aural perspectives, according to their proximity to the various smaller groups of musicians. The performance was heard five days later on the $\mathrm{CBC}$, but the radio audience heard the work from one perspective only, because it was broadcast in mono; stereo broadcasting was not introduced to Canada until the mid-1970s.

Kraglund not only wrote the advance article about the work, he also reviewed it for the Globe and Mail (Kraglund 1963b). He was a rather conservative critic and seldom had much good to say about new music, Canadian or otherwise, but on this occasion he delivered a positive, though measured verdict on the Somers work: it "provided more sonic excitement than this auditorium has heard in several seasons," he wrote. Reporting on the audience's reception of the work, he noted that it was not "received with equal enthusiasm by all, but few contemporary pieces have been given as sustained applause as this one." A week later, two letters to the editor appeared in the newspaper. In the first, an audience member wrote in to say that the Somers work was "cacophonous nonsense" and "musical charlatanry," and criticized Kraglund for having said anything good about it at all (Stables 1963). The second letter was from Heinz Unger, a Toronto resident and a distinguished conductor and Mahler specialist who had led the Berlin Philharmonic and many other fine orchestras in the course of a professional career stretching back more than forty years by that time. Unger began his letter by saying the performance was "one of the greatest experiences in sound which I can remember. If I use the word sound, and not music, it is because the impressions gained were on a higher level, not on a lower one, than just music" (Unger 1963). Twelve years later, in his fine biography of Somers, Brian Cherney wrote that Stereophony is "a deeply satisfying work on many levels, and at the same time, one of the boldest, most original works in the Canadian orchestral repertoire" (Cherney 1975, 103).

And yet Stereophony has been performed on only one other occasion. The second performance was in 1997 in the Barbara Frum Atrium, a 10,00o square 
foot, ten-storey open space that is the centrepiece of the CBC Broadcast Centre in Toronto; it is this performance, by the Toronto Symphony under JukkaPekka Saraste, that was released on CD (Somers 2011). One reason for the lack of performances may be that Stereophony requires the added effort of working out the physical disposition of the players in meticulous detail. This was by no means without precedent; Somers notes in his article about the work that Beethoven provided a famous earlier example-Leonore Overture No. 3, with its dramatic offstage trumpet call. The diagram Somers provides in the score for the disposition of the orchestral forces is rather complicated, though, and it may have been enough to scare off potential conductors of the work. Many composers in the 1960 os were fond of using complicated spatial dispositions of the orchestral forces, but few if any of those works have entered the common repertoire.

The fifth case study is of a work by Istvan Anhalt, who was born in Budapest in 1919. Anhalt's music has never had the recognition from performers that its quality merits, perhaps because he reached peak form only in retirement, after devoting thirty-five years to a career as a university professor and administrator. In addition, he lived and worked for the last forty years of his life in Kingston, Ontario, away from the major musical centres and media outlets. Nevertheless, he produced a body of work that speaks with force and eloquence about the contemporary human condition.

Symphony of Modules was a major work that occupied Anhalt from 1962 to 1967 . Compositional work on it was already well under way when Anhalt accepted a commission from the Canadian Music Centre and the Centennial Commission to complete the piece for a premiere performance by the Vancouver Symphony Orchestra at Simon Fraser University in 1967. That planned performance did not materialize, although the hope of getting the Vancouver orchestra to play the work dragged on for another three years. A performance under Lukas Foss in Buffalo was also discussed, as was a proposal from John Beckwith to have the University of Toronto Symphony Orchestra do the work in 1976. Nothing came of any of these plans, and it remains unperformed to this day. The Vancouver Symphony backed out of its commitment because it could not afford the forces and rehearsal time Anhalt required for the piece, which is scored for an orchestra with at least ninety-five players; more string players are to be added if available. Eight percussionists play sixty-four instruments; three people operate two two-channel stereo tape recorders and a mixing console to control the levels of contact microphones that are needed for some of the instruments; and the whole is to be directed by two conductors. Anhalt requested eighteen to twenty hours of rehearsal time, which the orchestra's general manager estimated in 1970 would entail $\$ 10,000$ in extra costs that was not available. 5 Despite the setbacks, Anhalt remained involved with the work intermittently for many years; as recently as the mid-199os a former student of

5 In a letter to John Beckwith in connection with the possible performance by Lukas Foss, Anhalt wrote, "I hope Foss will have 50 hrs. of rehearsals" for a dual premiere of Anhalt's Symphony of Modules and an unspecified new work by Lejaren Hiller (Beckwith 2001, 115). 
his was offering to assist in producing digital versions of the tape parts of the work; however, the tape component had never been completed because various planned performances were cancelled.

Despite the fact that Symphony of Modules has never been performed, it has taken on a new life as a work of graphic art. The tape parts for this twentyeight-minute work were never completed, but the score itself was finishedand it is in the oversize format that was favoured by avant-garde composers in the $1960 \mathrm{os}$. Copies of this large score ( $49 \mathrm{~cm}$ high by $60 \mathrm{~cm}$ wide) are available in the Canadian Music Centre and Queen's University libraries, and in the Anhalt papers at Library and Archives Canada, which also has four large boxes of sketches and diagrams for the work. Three pages of the score are included in Beckwith's article on the composition (Beckwith 2001, 118-19 and 121). A page of the manuscript score also appears in John Cage's book Notations (1969, n.p.); this page later provided the inspiration for the Daeyang Gallery and House in Seoul, Korea, by the architect Steven Holl. The architectural plans for this building were begun in 2008 and the building was finished in 2012, the year of Anhalt's death; viewed from above, the shape of the building is nearly identical with the geometrical design of Anhalt's score page (Kennicott 2013).

The modules referred to in the title are small motivic building units that are strung together in what Anhalt calls modular construction; it is similar to what others have termed moment form in the music of Stockhausen and other composers. The work calls for extended performance techniques and includes four cadenzas that are partly indeterminate and written in graphic notation. Anhalt also makes use of collage techniques, quoting from Strauss's Till Eulenspiegels lustige Streiche and Brahms's German Requiem, among other works. Indeed, the symphony is a veritable encyclopedia of compositional practices of the $1960 \mathrm{os}$. At the end of his analysis of the work, Beckwith asks whether it will ever be performed and concludes, "It clearly deserves to be" (Beckwith 2001, 120). He compares it to Ives's Fourth Symphony and notes that that piece had to wait forty-nine years until its first complete performance. By that calculation, Symphony of Modules is due for performance in 2016.

The sixth and final case study is of a work by R. Murray Schafer. Schafer's engagement with the orchestra dates back fifty-five years to In Memoriam Alberto Guerrero of 1959 for string orchestra; it is a tribute to his piano teacher, who was also the teacher of Glenn Gould and a host of other leading Canadian musicians. This is the earliest piece by Schafer on Reid and Clark's list of popular Canadian orchestral works. Schafer has seven works on that list, more than any other composer. On Foster's list he is the most performed Canadian composer of orchestral music between 1980 and 2005 .

Schafer's Lustro is a triptych of three substantial works for large orchestra, eight singers, and electronic sounds. The three component parts of Lustro, each of which can be performed as a separate work, are Divan i Shams i Tabriz, Music for the Morning of the World, and Beyond the Great Gate of Light. The first two parts are set to poetry by the thirteenth-century mystic Jalal al-Din Rumi, founder of the Sufi sect known as the dervishes; the first movement uses the original Persian, while the second uses an English translation. The text of 
the third movement is from a poem by Rabindranath Tagore, set in Bengali. The word Lustro is a Latin verb meaning "I illuminate" or "I purify"; the texts deal with the sun, and beyond that with physical love, religious ecstasy, and mystical union with God; however, in performance most of the text is either inaudible or unintelligible.

The score of Divan $i$ Shams $i$ Tabriz (Poems of the sun of Tabriz) includes famous examples of graphic notation; pages 30-31 were used by Universal Edition for the cover illustration of all of Schafer's music that the company published and have often been reproduced in other contexts. This first section of Lustro was written for the Vancouver Symphony Orchestra but, as with Anhalt's Symphony of Modules, the orchestra never performed the work. Schafer's composition, like Stereophony, places the orchestra not just on stage but also spread around the hall: in Schafer's work, there are thirteen mixed quintets of instruments and solo singers, each with a stopwatch to co-ordinate their efforts. Schafer has explained how this created problems in Vancouver: "[The spatial distribution] would involve removing some of the seats. A dubious manager accompanied me with a seating plan showing which seats belonged to regular subscribers. 'But we can't move Mr. and Mrs. X! They've been patrons of the orchestra for fifty years!' I countered: 'I've always wanted to move people with my music and I'm not going to give up now!' But in the end a confederation of pedestrian regulations and managerial timidity defeated the planned première" (Schafer 2015). It thus fell to a student orchestra, the University of Toronto Symphony Orchestra, to give the premiere of the work in 1972.

Music for the Morning of the World is linked to the first section of Lustro by setting a text by the same poet, but otherwise occupies a different world altogether. It is scored for soprano and four-channel tape, with one speaker in each corner of the hall. The original analogue version of the tape part has recently been restored and digitized for a recording of the second part of Lustro, which was released on the Centrediscs label (Schafer 2006). At the end of Divan $i$ Shams $i$ Tabriz the lights are to dim, and Music for the Morning of the World is to be sung in the dark, illuminated by a single candle. During the third part of Lustro the lights slowly rise. Beyond the Great Gate of Light is scored for the same forces as Divan i Shams i Tabriz; in theory it too can be detached from Lustro and performed as an independent work, but in practice this has never yet been done. The work ends with a shimmering G-major triad, which is sustained for a full six minutes.

There has been just one single performance of Lustro in its entirety, given by the Toronto Symphony under the French conductor Marius Constant on 31 May 1973. The performance was recorded for subsequent broadcast on CBC Radio and was one of the most elaborate undertakings the $\mathrm{CBC}$ had ever attempted. To make the broadcast recording, the audio supervisor employed ten technicians, who were in charge of a vast array of recording and mixing equipment, including twenty-five microphones and 6000 feet of audio cable (Anonymous 1973; Adams 1983, 194n11). A stumbling block to further performances of Lustro is that the orchestra has nothing to play for a large portion of the composition; for over half an hour of the seventy-five-minute work, the orchestra is silent. 
Nevertheless, in the opinion of Stephen Adams, this is Schafer's "single greatest composition" (Adams 1983, 108), so it is a pity that it has been performed only once.

\section{Conclusion}

Many reasons have led to the neglect of these six Canadian orchestral works: losing the manuscript of the composition, alienating the conductor who premiered the work, writing for a soloist who does not like the music, using a complicated disposition of orchestral forces, or making the work difficult and expensive to perform in other ways.

The works mentioned here are merely the tip of a veritable Canadian iceberg of neglected orchestral music. There were over 2,500 Canadian orchestral scores in 2001, and only 122 of them made it into Reid and Clark's list of popular Canadian orchestral music. Similarly, in Foster's list of 934 Canadian orchestral works played between 1980 and 2005, 677 of them were heard only once. There have been attempts to get a hearing for some of these scores; the Creators' Assistance Program for many years sponsored professional reading sessions of orchestral works by Canadian composers that had never previously been recorded or given a public performance (the program was terminated by the federal government in 2013). The Esprit Orchestra in Toronto has been devotedly performing Canadian orchestral music ever since it was founded in 1983 and often gives repeat performances of works that it has programmed. But the rest of that musical iceberg is still waiting to be discovered.

\section{REFERENCES}

Adams, Stephen. 1983. R. Murray Schafer. Toronto: University of Toronto Press. Anonymous. 1963. "Worth Reporting." Music across Canada 1 (2): 29.

_.1973. "The Story behind Taping of Lustro." CBC Radio Network Promotion, No. 176 (28 August).

Beckwith, John. 2001. "Orchestral Works." In Istvan Anhalt: Pathways and Memory, ed. Robin Elliott and Gordon E. Smith, 111-31. Montreal and Kingston: McGill-Queen's University Press.

2002. Letter to the editor. Prairie Sounds 51 (Spring): 3 .

Beckwith, John, and Brian Cherney, eds. 2011. John Weinzweig: Essays on His Life and Music. Waterloo, ON: Wilfrid Laurier University Press.

Cage, John. 1969. Notations. New York: Something Else.

Cherney, Brian. 1975. Harry Somers. Toronto: University of Toronto Press.

Cook, Nicholas. 1993. Cambridge Music Handbooks: Beethoven Symphony No. 9. Cambridge: Cambridge University Press.

Diamond, Beverley. 2000. "What's the Difference? Reflections on Discourses of Morality, Modernism, and Mosaics in the Study of Music in Canada." Canadian University Music Review / Revue de musique des universités canadiennes 21 (1): 54-75.

Elliott, Robin. 2014. "Fact and Fiction in the Life Story of Luigi von Kunits." Nineteenth-Century Music Review 11 (2): 239-54. 
Fraser, Robert John. 2008. "The Programming of Orchestral Music by Canadian Composers, 1980-2005." MA thesis, University of Victoria.

Kallmann, Helmut, ed. 1990. The Canadian Musical Heritage. Vol. 8, Music for Orchestra I. Ottawa: Canadian Musical Heritage Society.

Keillor, Elaine, ed. 1994. The Canadian Musical Heritage. Vol. 15, Music for Orchestra II. Ottawa: Canadian Musical Heritage Society.

Kennicott, Philip. 2013. "Music Holl: A Copper-Clad Pavilion in Seoul." Dwell: At Home in the Modern World 13 (6), http://www.dwell.com/house-tours/ article/music-holl-copper-clad-pavilion-seoul.

Kraglund, John. 1963a. "Stereo Comes Alive for TSO." Globe and Mail, 16 March.

__ 1963b. "Massey Hall Rings with Somers' Sound." Globe and Mail, 20 March.

Lefebvre, Marie-Thérèse. 2004. Rodolphe Mathieu 1890-1962: L'émergence du statut professionnel de compositeur au Québec. Sillery, QC: Septentrion.

Mazzoleni, Ettore. 1942. "The Orchestra." Canadian Review of Music and Art $1(2): 5-7,16$.

Oja, Carol J. 1984. “Colin McPhee: A Composer Turned Explorer." Tempo 148 (March): 2-6.

-1990. Colin McPhee: Composer in Two Worlds. Urbana: University of Illinois Press. Reprint 2004.

Potvin, Gilles. 1969. "Performers." In Aspects of Music in Canada, ed. Arnold Walter, 143-66. Toronto: University of Toronto Press.

—_ 1981. "Colin McPhee." Encyclopedia of Music in Canada, ed. Helmut Kallmann, Gilles Potvin and Kenneth Winters, 585. Toronto: University of Toronto Press.

Reid, John C., and Bob Clark. 2001. "The Changing Tide for Canadian Orchestral Music." In Musicanada 20oo: A Celebration of Canadian Composers, ed. S. Timothy Maloney, 143-50. Montreal: Éditions Liber / Canadian Music Centre.

Renaud, Lucie. 2009. Liner notes to a recording of André Mathieu's Concertino for Piano and Orchestra, trans. Peter Christensen. Analekta CD AN 29283.

Schafer, R. Murray. 1984. “The Future for Music in Canada." In On Canadian Music, 39-47. Bancroft, ON: Arcana.

- 2006. Lustro from R. Murray Schafer: 3 Solos. Annie Tremblay, soprano; digital transfer of the original 4-track analogue tape part realized by Morris Apelbaum, Tim Brady, and Dominique Bassal. Centrediscs CMCCD/ DVD 12006.

- 2015. Program note for Divan i Shams i Tabriz (1970), http://www.patria .org/arcana/Programnotes.pdf.

Somers, Harry. 1963. "Stereophony for Orchestra." Music across Canada 1 (2): $26-28$.

-2011. Live from Toronto-Harry Somers. Centrediscs CMCCD 15911.

Stables, Joseph. 1963. Letter to the editor. Globe and Mail, 27 March.

Unger, Heinz. 1963. Letter to the editor. Globe and Mail, 27 March. 
Winters, Kenneth. 1981. "Orchestras.” In Encyclopedia of Music in Canada, ed. Helmut Kallmann, Gilles Potvin, and Kenneth Winters, 703-08. Toronto: University of Toronto Press.

\begin{abstract}
This article examines neglected orchestral works by six Canadian composers: Rodolphe Mathieu, Colin McPhee, John Weinzweig, Harry Somers, Istvan Anhalt, and R. Murray Schafer. Despite the considerable professional accomplishments and career achievements of these composers, each has at least one orchestral work in his catalogue that failed to make a good impression with the musical public or has never been heard in live performance. The article attempts to find why these compositions did not win a place in the repertoire and also considers how these works illustrate broader issues relating to the Canadian orchestral repertoire.
\end{abstract}

\title{
RÉSUMÉ
}

Cet article examine une série d'œuvres orchestrales de six compositeurs canadiens: Rodolphe Mathieu, Colin McPhee, John Weinzweig, Harry Somers, Istvan Anhalt, et R. Murray Schafer. Malgré les réalisations professionnelles considérables et les carrières remarquables de ces compositeurs, chacun d'entre eux a composé au moins une œuvre orchestrale qui n’a pas emporté l'adhésion du public ou qui n'a même jamais été créée en concert. Dans cet article, on tente de compendre pourquoi ces compositions ne se sont pas taillé une place dans le répertoire, ce qui soulève des questions plus générales au sujet du répertoire orchestral canadien. 